\title{
A Case of Acute Supraglottitis Following Anti-Thyroid Drug-Induced Agranulocytosis
}

\author{
Jung Jun Lee ${ }^{(\mathbb{B}}$, Dong Young Kim (1), and Jeon Yeob Jang (1) \\ Department of Otolaryngology, Ajou University School of Medicine, Suwon, Korea \\ 항갑상선제 부작용으로 인한 무과립구증에 속발한 급성 성문상부염 1 예 \\ 이정준, 김동영, 장전엽 \\ 아주대학교 의과대학 이비인후과학교실
}

Acute supraglottitis is characterized by an inflammation and edema of the supraglottic region and a potential life-threatening condition because of its risk for sudden upper airway compromise. Prompt diagnosis, administration of broad spectrum antibiotics, and airway management is pivotal for reducing serious complications. In the immunocompromised host, microorganisms are more likely to elicit mucosal inflammations, thus clinicians should pay attention to those patients for prompt removal of the causes of immune disruption. Here we report a case of acute adult supraglottitis with neutropenia caused by anti-thyroid drug with a review of the related literatures.

Keywords Supraglottitis; Epiglottitis; Antithyroid agents; Agranulocytosis.

\section{서 론}

급성 성문상부염은 성문상부 구조물의 감염으로부터 기인하며, 가성대, 모뿔연골, 후 두실, 설근편도, 후두개, 그리고 설근 등의 부종으로 급진적인 상기도 협착을 초래하여 수 시간 이내에 기도 폐쇄 등의 증상이 악화될 수 있다. 따라서, 원인에 대한 적절한 진 단과 치료를 신속히 시행하는 것이 중요하다. ${ }^{1-3)}$ 원인 균은 B형 Haemophilus influenzae가 가장 흔하며, Pneumococcus나 $\beta$-hemolytic streptococcus 등에 의해서도 발생 할 수 있다고 알려져 있다. ${ }^{45}$ 성문상부염은 소아에서 호발하나, B형 Haemophilus influenzae에 대한 예방접종이 시행된 이후 그 빈도는 감소하고 있다. 그러나, 대부분의 역학 연구에서 성인에서는 그 빈도가 같거나 혹은 증가한다고 보고하고 있다. 2,6)

급성 성문상부염은 면역반응이 저하된 면역기능저하 환자에서 감염의 형태로 발생할 수 있다. ${ }^{78}$ 면역기능저하를 일으키는 원인은 다양하며, 암과 항암치료, 인체면역결핍 바 이러스, 장기이식 후 면역억제제의 복용, 감염성 단핵구증 그리고 약물에 의해 2차적으 로 발생한다.9) 면역기능저하를 일으키는 약제는 매우 다양한데, 그중 항갑상선제는 이비 인후과 영역에서 흔하게 복용 약물로 확인되며, 대표적이며 치명적인 합병증으로 무과립
Received July 2, 2019

Revised July 29, 2019

Accepted August 6, 2019

\section{Corresponding Author}

Jeon Yeob Jang, MD, PhD

Department of Otolaryngology, Ajou University School of Medicine, 164 World cup-ro, Yeongtong-gu, Suwon 16499, Korea

Tel +82-31-219-5138

Fax+82-31-219-5264

E-mail manup1377@gmail.com

\section{ORCID iDs}

Jung Jun Lee (D)

https://orcid.org/0000-0002-5870-6140

Dong Young Kim (D)

https://orcid.org/0000-0002-2746-0790

Jeon Yeob Jang (D)

https://orcid.org/0000-0002-9047-4896

This is an Open Access article distributed under the terms of the Creative Commons Attribution Non-Commercial License (https://creativecommons.org/ licenses/by-nc/4.0) which permits unrestricted non-commercial use, distribution, and reproduction in any medium, provided the original work is properly cited. 
구증으로 인한 면역기능저하가 있다. ${ }^{10)}$ 본 저자는 인후통을 주소로 내원한 환자에서 급성 성문상부염을 진단하였고, 항 생제 치료를 시작하였으나, 그 임상적 경과가 호전되지 않고 혈액검사 결과 무과립구증이 발견되어, 추가적인 문진을 통해 항갑상선제의 복용을 확인하였다. 이후 즉각적인 항갑상선제 복용의 중단 그리고 광범위 항생제 및 granulocyte colony stimulation factors $(\mathrm{G}-\mathrm{CSF})$ 의 투여를 시행하여 환자를 치료 하였기에, 문헌 고찰과 함께 본 증례를 보고하는 바이다.

\section{증 례}

38세 여자 환자가 내원 6일 전부터 발생한 호흡곤란, 인후 통을 주소로 응급실로 내원하였다. 계통 문진상 호흡곤란, 인 후통, 연하통을 호소하였으며, 이학적 검사상 38.3 도의 발열, 설근편도 비대, 후두개, 모뿔연골 부위 점막의 궤양, 종창 및 발적(Fig. 1)이 관찰되었다. 산소포화도는 $97 \%$ 로 정상 범위였 으며, 응급실 내원 당시 시행한 혈액검사 결과 white blood cell(WBC) 300/ $\mathrm{LL}$, erythrocyte sedimentation rate(ESR) 93 $\mathrm{mm} / \mathrm{hr}$, C-reactive protein(CRP) $22.04 \mathrm{mg} / \mathrm{dL}$ 확인되었다. 이에 중증 백혈구 감소증 및 급성 성문상부염으로 진단하에 광범위 항생제(4세대 세팔로스포린 및 클린다마이신)을 정맥 투여하였다. 환자는 응급실 내원 당시에는 특이 과거력이 없 었다고 표현하였으나, 재차 복용 약물에 대해 문진한 결과 2008년 그레이브스병 진단하에 1년간 propylthiouracil을 복 용하였고, 이후 2013년 재발하여 1년간 methimazole을 복용 하였으며, 2017년 4월 다시 재발하여 methimazole을 하루 용 량 $30 \mathrm{mg}$ 복용하고 있었던 과거력이 확인되었다.

중증 백혈구 감소증에 대한 평가 및 처치를 위해 혈액종양 내과에 협의 진료를 시행하였고, 그 결과 $\mathrm{G}-\mathrm{CSF}$ 를 하루 1 회 $300 \mu \mathrm{g}$ 의 용량으로 투여하며 격리 치료를 시작하였다. 항갑상 선제 복용 및 합병증에 대한 평가를 위하여 내분비대사내과 에 협의 진료를 시행한 결과, methimazole에 의한 무과립구 증일 가능성이 높다는 소견이었으며 내원 2일째부터 methimazole 약물 투여를 중단하였다. 내원 4일째 시행한 이학 적 검사상 후두개 종창 및 발적이 감소한 모습이 관찰되었고 (Fig. 2A), 혈액검사상 WBC $8100 / \mu \mathrm{L}$, absolute neutrophil count(ANC) 1700/ $\mu \mathrm{L}$, ESR $83 \mathrm{~mm} / \mathrm{hr}$, CRP $4.15 \mathrm{mg} / \mathrm{dL}$ 로 백혈구 수는 증가하는 추세이며 염증 수치는 감소하는 소견 을 확인하였다. 내원 5일째 혈액검사상 WBC 23700/L, ANC $13272 / \mu \mathrm{L}$ 로 확인되어 $\mathrm{G}-\mathrm{CSF}$ 투여를 중단하였고, 내원 6일

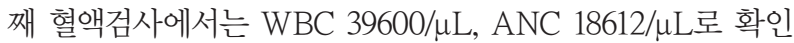
되었다. 이후 백혈구 수치는 점차 감소하여 내원 11일째에

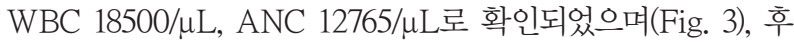

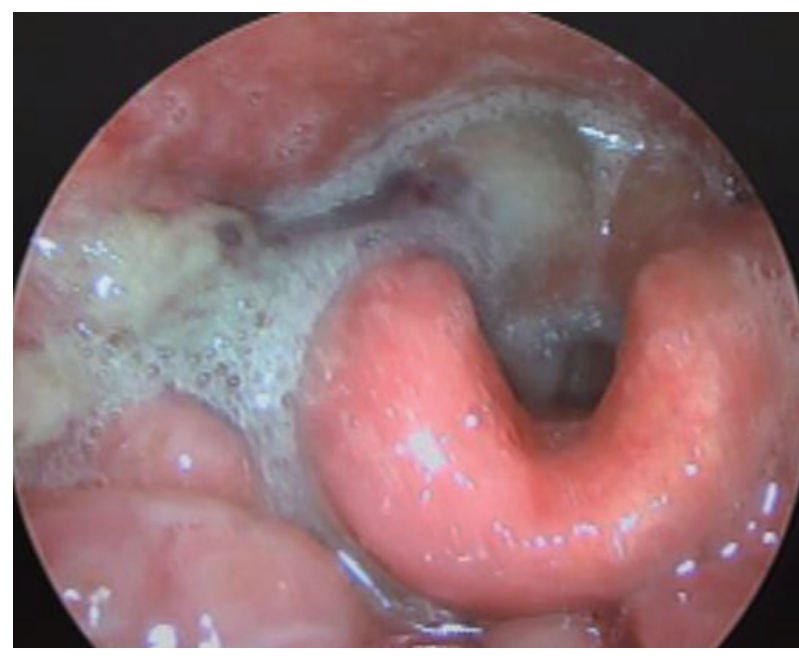

Fig. 1. Laryngoscopy image of supraglottis showing erythematous, erosive, and edematous mucosa of epiglottis, arytenoid, aryepiglottic fold.
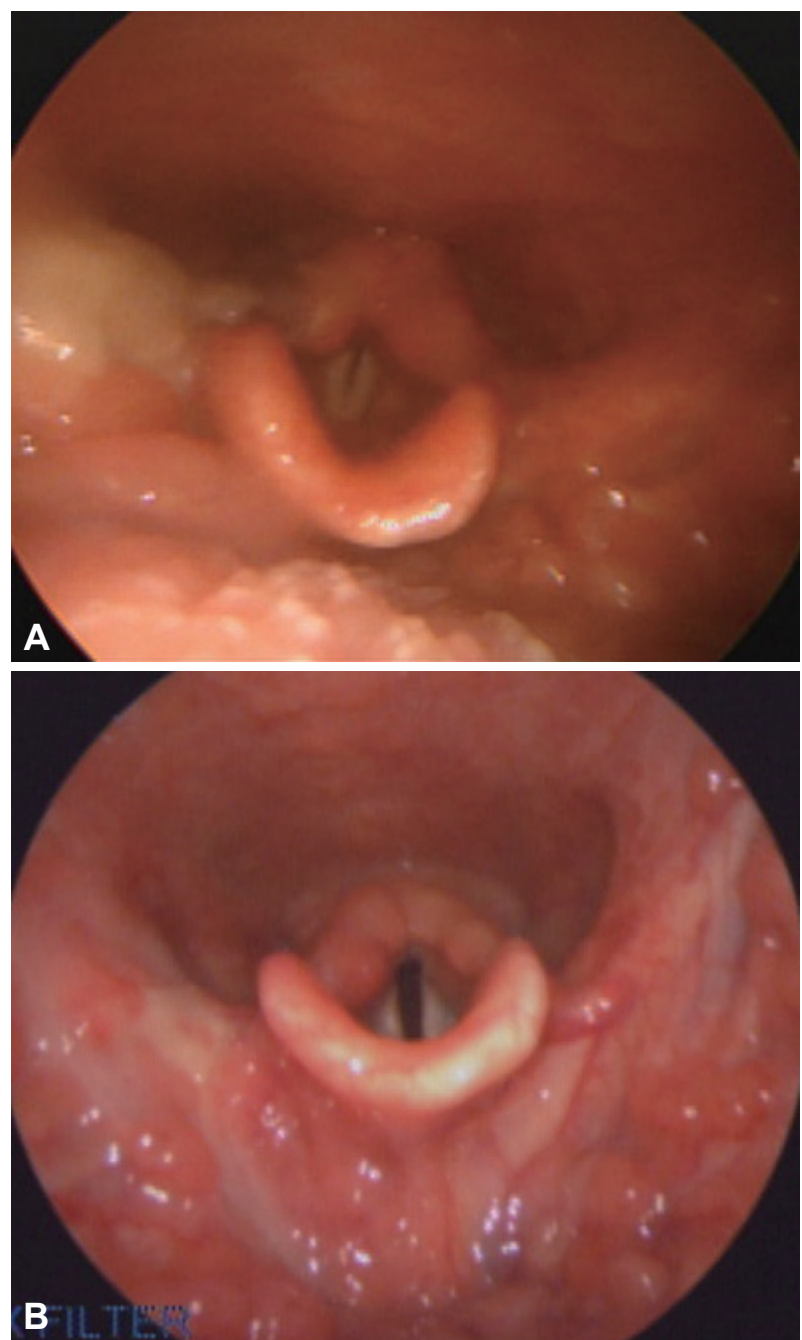

Fig. 2. Follow-up laryngoscopy image at post-admission 4 days showing significant improvement in erythema and swelling $(A)$. Follow-up laryngoscopy image at post-admission 11 days showing resolution of erythema and swelling (B). 


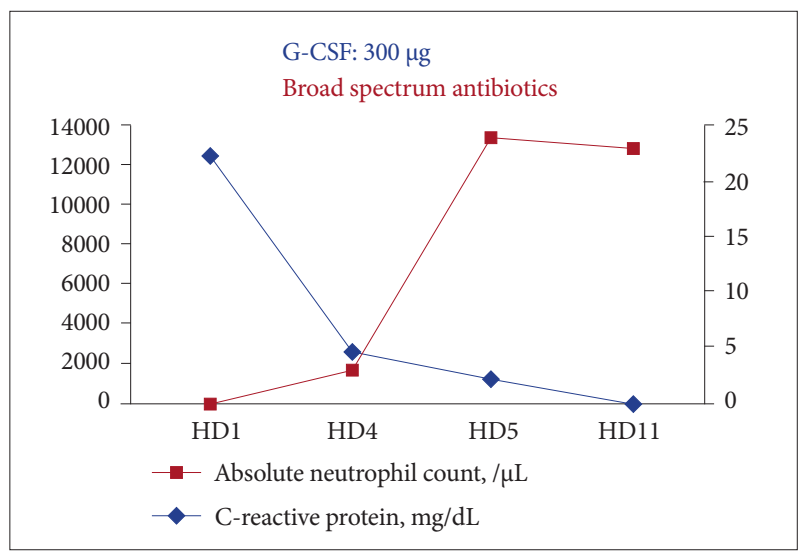

Fig. 3. Clinical course of the patient. G-CSF: granulocyte colonystimulating factor, HD: hospital days, broad spectrum antibiotics: 4th cephalosporin, clindamycin.

두내시경검사상 모뿔연골과 후두개 부위 점막의 종창 및 발적 이 해소(Fig. 2B)되어 퇴원하였다. 퇴원 후 6일째에 외래로 추 적 방문 하였고, $\mathrm{WBC} 6000 / \mu \mathrm{L}, \mathrm{ANC} 3354 / \mu \mathrm{L}$ 로 정상화되었 으며, 후두내시경검사상 우측 성문상부의 경한 점막 궤양 외 에 특이소견 없이 성문상부염이 호전된 양상으로 관찰되었다.

이후 환자는 퇴원 후 핵의학과에 협의 진료를 시행하여 그 레이브스병에 대하여 항갑상선제 대신에 방사선요오드치료 를 시행하였다. 이후 환자는 levothyroxine $112.5 \mu \mathrm{g}$, liothyronine $12.5 \mu \mathrm{g}$ 을 복용 중이며, 6 개월 뒤에 시행한 갑상 선기능검사는 정상 범위로 측정되었으며 외래 추적 관찰 중 백혈구 감소증은 관찰되지 않았다.

\section{고 찰}

급성 성문상부염은 임상적으로 응급질환으로 상기도의 염 증성 반응으로 인한 종창 및 발적으로 치명적인 결과를 초래 할 수 있다. 임상증상으로 인후통과 연하곤란을 대부분 호 소하며, 마치 뜨거운 감자를 먹은 듯한 목소리 변화가 특징 이다.411) 급성 성문상부염의 진단은 병력청취, 신체검사, 영상 검사, 후두경검사 등을 통해 이루어지며, 후두개의 설근부에 서부터 진성대 상부까지를 포함한 성문상부 조직의 종창을 볼 수 있고 간혹 농양이 형성되는 경우도 있다. 호흡곤란으 로 후두경검사가 불가능할 경우, 조영증강 경부 전산화단층 촬영으로 성문상부염을 확인할 수 있다.,11) 본 증례에서도 환 자는 인후통, 연하곤란 그리고 호흡곤란을 호소하며 응급실 로 내원하여 이학적 검사 및 후두경검사를 시행하였고, 후두 개에서부터 진성대 상부까지를 포함한 성문상부의 종창과 발적, 그리고 점막의 광범위한 궤양을 확인하였다.

성문상부염의 치료의 원칙은 기도의 확보가 우선시되어야
하며, 이를 위하여 필요 시 기관절개술 및 기관 내 삽관 등의 처치가 즉시 이루어져야 한다. 성문상부염으로 내원한 환자 중 약 $21 \%$ 는 기도확보를 위한 중재적 시술을 필요로 한다고 보고된 바 있다. ${ }^{11)}$ 약물치료는 그람 양성균과, Haemophilus influenza를 포함할 수 있는 광범위 항생제의 투여와 스테로 이드 등의 약물 치료를 요하며, 보통 임상적 경과는 36 48시 간 이내에 호전되는 양상을 보이나 그렇지 않거나 재발성의 경우 다른 기저질환 등의 원인, 즉 악성종양, 림프종, 아밀로 이드증, 육아종증 그리고 면역기능부전을 고려해야 한 다.5,6,12) 본 증례에서 환자는 광범위 항생제 투여에도 초기에 는 임상적으로 호전되는 경과를 보이지 않았다. 더불어 급성 성문상부염 환자의 약 65 90\%에서 평균적으로 $15000 / \mu \mathrm{L}$ 정도의 백혈구 증가가 확인되는 것이 비해, ${ }^{2)}$ 본 증례에서는 $300 / \mu \mathrm{L}$ 의 중증 백혈구 감소증이 확인되었다. 이에 재문진을 시행한 결과 복용 중이던 항갑상선제의 합병증으로 인한 무 과립구증을 확인하게 되었다.

항갑상선제인 propylthiouracil, methimazole은 1943년 처 음 사용된 이후 접근이 용이하며 환자의 순응도가 좋아, 반 세기 동안 갑상선기능항진증에 1차 약제로 널리 사용되어 왔 다. 부작용으로는 1 5\%에서 두드러기, 발진, 관절통 등의 경 미한 반응을 일으킬 수 있고, 심하게는 무과립구증, 독성간 염, 담즙정체, 혈관염 등을 일으킬 수 있다. 이 중 0.1 0.5\%에 서 발생하는 무과립구증은 과립구 수치가 $500 / \mu \mathrm{L}$ 이하로 정 의되며 가장 치명적인 부작용으로 분류된다. ${ }^{10,13)}$ 항갑상선제 에 의한 무과립구증의 확실한 병인은 알려진바 없으며, $\mathrm{CoO}^{-}$ $\mathrm{per}^{14)}$ 에 따르면 methimazole의 투여 용량이 많을수록 무과 립구증의 발생 빈도가 높다고 보고된다. 대부분의 문헌에서 무과립구증은 치료 후 3 개월 이내에 발생하며, 증상으로 인 후통, 열감, 오한 등이 있으나 무증상인 상태로 수 일에서 수 개월간 지내는 환자가 상당수에 이른다고 보고된다. ${ }^{13)}$ 본 증 례에서도 환자는 이전에 2차례 methimazole을 각 1년간 복 용하였던 과거력이 있었고 당시에는 특이 합병증이 없었으나, 성문상부염으로 진단되기 1달 전 methimazole 용량을 10 $\mathrm{mg}$ 에서 $30 \mathrm{mg}$ 으로 증량 후 무과립구증이 발생하였다. 이와 같이 무과립구증과 동반하여 상기도 폐쇄를 일으키는 심한 감염을 일으키는 경우는 임상적으로 중요함에도, ${ }^{10,14)}$ 현재까 지 문헌 고찰에서 procanamide에 의한 급성후두개염 외에 는 약물에 의한 면역기능저하로 인한 급성 성문상부염의 증 례가 보고된 바 없었다. ${ }^{8}$

무과립구증의 치료는 즉시 항갑상선제를 끊고 신속히 광 범위 항생제 사용과 보존적 치료를 하면 대부분 회복된다고 알려져 있으나, 일부에서는 패혈증으로 사망하는 등의 치명 적인 경우가 보고되기 때문에, 임상적 경과를 면밀히 관찰해 
야 한다. ${ }^{10)}$ 혈액성장인자, 즉 $\mathrm{G}-\mathrm{CSF}$ 나 granulocyte-macrophage colony-stimulating factor(GM-CSF)는 조혈세포 의 성장 인자로서 항암화학요법, 방사선치료, 약물 등으로 인 해 초래되는 백혈구 감소증의 치료에 널리 사용되고 있다. 다 만 항갑상선제로 인한 무과립구증에서의 $\mathrm{G}-\mathrm{CSF}$ 의 사용은 논란의 여지가 있다. Fukata 등 ${ }^{15)}$ 은 전향적 무작위 대조군 연구에서 G-CSF 투여한 군과 투여하지 않은 군 사이에 무 과립구증의 회복에 유의한 차이가 없다고 보고한 바 있으나, 많은 연구에서 호중구 감소의 기간을 단축시키고 입원 기간 을 줄이는 효과가 있어 과립구 수를 정상화시키는 데 있어 권 고되고 있다. ${ }^{14)}$

항갑상선제에 의한 무과립구증은 그 발생 빈도가 매우 낮 으나 치명적인 합병증을 일으킬 수 있으므로 주의가 필요하 다. 그 합병증으로 구내염, 편도염, 인후두염으로 임상적 발현 이 될 수 있으나, 패혈증, 성문상부염, 심경부농양과 같은 치 명적인 질환으로 발현될 수도 있다. 이비인후과 영역에서 급 성 성문상부염을 진단하였을 때, 상기도 폐쇄를 포함한 해부 학적 평가가 우선시되는 상황이기에 장기간 특이 합병증 없 이 항갑상선제를 사용하고 있었던 환자에서 무과립구증에 대한 주의가 부족해지기 쉽다. 항갑상선제를 사용하는 중에 는 그 기간에 상관없이 언제든지 무과립구증이 발생될 수 있 음을 항상 고려해야 할 것으로 사료된다. 저자는 본 증례에 서 성문상부염으로 내원한 환자에게서 혈청학적 소견상 무 과립구증을 진단하였으며 이에 대한 원인 약제인 항갑상선 제를 과거력 문진을 통해 확인하였다. 이후 광범위 항생제 및 $\mathrm{G}-\mathrm{CSF}$ 를 사용하여 성공적으로 치료하여 이를 문헌 고찰과 함께 보고하는 바이다.

중심 단어: 성문상부염, 급성후두개염, 항갑상선제, 무과립 구증.

\section{Acknowledgments}

None.

Conflicts of Interest

The authors have no financial conflicts of interest.

Authors' Contribution

Conceptualization: Jeon Yeob Jang. Data curation: Jung Jun Lee,
Dong Young Kim. Resources: Jeon Yeob Jang. Supervision: Jeon Yeob Jang. Writing_original draft: Jung Jun Lee. Writing_-review \& editing: Jeon Yeob Jang. Approval of final manuscript: all authors.

\section{REFERENCES}

1. Byun JY, Lee BH, Hwang JH, Jin DS, Chai YH, Lee KO. Acute supraglottitis in adults. Korean J Otorhinolaryngol-Head Neck Surg 1995;38(8):1251-6.

2. Navaratnam AV, Smith ME, Majeed A, McFerran DJ. Adult supraglottitis: a potential airway emergency that can present in primary care. Br J Gen Pract 2015;65(631):99-100.

3. Kim BJ, Choi BG, Choi HG, Lee JY, Park BJ. A clinical study of acute epiglottitis: retrospective review of 315 patients in Korea. Korean J Otorhinolaryngol-Head Neck Surg 2019;62(4):233-7.

4. Guldfred LA, Lyhne D, Becker BC. Acute epiglottitis: epidemiology, clinical presentation, management and outcome. J Laryngol Otol 2008;122(8):818-23.

5. Al-Qudah M, Shetty S, Alomari M, Alqdah M. Acute adult supraglottitis: current management and treatment. South Med J 2010; 103(8):800-4.

6. Shah RK, Stocks C. Epiglottitis in the United States: national trends, variances, prognosis, and management. Laryngoscope 2010;120(6): 1256-62.

7. Lee ACW, Lam SY. Life threatening acute epiglottitis in acute leukemia. Leuk Lymphoma 2002;43(3):665-7.

8. Chen C, Natarajan M, Bianchi D, Aue G, Powers JH. Acute epiglottitis in the immunocompromised host: case report and review of the literature. Open Forum Infect Dis 2018;5(3):ofy038.

9. Nagaraja V, Stewart TE, Mackay SG, Glenn DW, Wakefield D, Boutlis CS. Supraglottitis due to group B streptococcus in an adult with IgG4 and C2 deficiency: a case report and review of the literature. Laryngoscope 2015;125(4):852-5.

10. Vicente N, Cardoso L, Barros L, Carrilho F. Antithyroid drug-induced agranulocytosis: state of the art on diagnosis and management. Drugs R D 2017;17(1):91-6.

11. Guardiani E, Bliss M, Harley E. Supraglottitis in the era following widespread immunization against Haemophilus influenzae type B: evolving principles in diagnosis and management. Laryngoscope 2010;120(11):2183-8.

12. Bizaki AJ, Numminen J, Vasama JP, Laranne J, Rautiainen M. Acute supraglottitis in adults in Finland: review and analysis of 308 cases. Laryngoscope 2011;121(10):2107-13.

13. Kim HK, Yoon JH, Jeon MJ, Kim TY, Shong YK, Lee MJ, et al. Characteristics of Korean patients with antithyroid drug-induced agranulocytosis: a multicenter study in Korea. Endocrinol Metab (Seoul) 2015;30(4):475-80.

14. Cooper DS. Antithyroid drugs. N Engl J Med 2005;352(9):905-17.

15. Fukata S, Kuma K, Sugawara M. Granulocyte colony-stimulating factor (G-CSF) does not improve recovery from antithyroid drug-induced agranulocytosis: a prospective study. Thyroid 1999;9(1):29-31. 